\title{
Why People Hesitate To Help: Investigating the Relationship Between Stigma and Help-Giving Attitude
}

\author{
Franz A. Nurdiyanto and Diana Setiyawati \\ Faculty of Psychology \\ Universitas Gadjah Mada
}

\begin{abstract}
Mental disorders have become a prominent global burden of disease and their prevalent rate has increased by $37.6 \%$ in 1990-2010. In Indonesia, the prevalence of people with severe mental illness was approximately 1-2 out of 1,000 people. Unfortunately, the provisions of mental health services are still insufficient compared to the public need. It is difficult to find mental health services. People with mental illness also rarely receive an appropriate treatment they need. Furthermore, misconceptions on mental illness have made the society hesitate to help. This research aimed to investigate the correlation between public stigma and mental health help-giving attitude. There were 203 participants (Male $n=44$ ) from psychology, medicine, and nursing programs involved in the research. They completed public stigma scale and attitude towards mental health help-giving scale. A correlational analysis using the Charles Spearman's rank-order correlation revealed a negative correlation of - .47 ( $p<$ .05 ). Based on the result, public stigma was related to mental health help-giving. There was no difference between males and females in mental health help-giving.
\end{abstract}

Keywords: public stigma, mental health help-giving, treatment gap

Gangguan mental merupakan global burden disease dan meningkat 37.6\% sepanjang 19902010. Penderita gangguan mental berat di Indonesia juga diperkirakan mencapai 1-2 orang setiap 1.000 penduduk. Pada sisi lain, ketersediaan layanan kesehatan mental belum dapat memenuhi kebutuhan masyarakat. Hal ini diperparah dengan pemahaman yang keliru mengenai gangguan mental, membuat masyarakat tidak memberikan pertolongan kepada penderita. Tujuan penelitian ini adalah untuk mengetahui hubungan antara stigma publik gangguan mental terhadap sikap memberikan pertolongan kesehatan mental. Penelitian ini melibatkan 203 responden $(n$ laki-laki $=44)$ berupa mahasiswa psikologi, kedokteran, dan keperawatan. Responden memberikan jawaban pada skala stigma publik gangguan mental dan skala sikap memberikan pertolongan kesehatan mental. Hasil uji korelasi tata-jenjang Spearman menunjukkan terdapat korelasi negatif antara stigma publik dan sikap memberikan pertolongan kesehatan mental $(r=-.47 ; p<.05)$. Semakin tinggi stigma publik semakin rendah sikap memberikan pertolongan kesehatan mental. Penelitian ini juga menemukan tidak ada perbedaan sikap memberikan pertolongan kesehatan mental antara laki-laki dan perempuan.

Kata kunci: stigma publik, sikap memberikan pertolongan kesehatan mental, kesenjangan pengobatan

The prevalence of mental disorders is reported to be high in the global scale. WHO (2001) estimates that $25 \%$ of the world's population has experienced mental disorders throughout their lives, such as depression, anxiety and schizophrenia. The report also explains that more than $24 \%$ of patients in primary healthcares have been diagnosed with mental disor-

Correspondence concerning this article should be addressed to Franz A. Nurdiyanto Faculty of Psychology Universitas Gadjah Mada, Jalan Sosiohumaniora 1 Yogyakarta 55281. E-mail: franznur@gmail.com ders. At first they came with complaints of physical illness, but medical examinations showed no illness. Along with this development, mental disorders are projected as the second global burden disease by 2030 after HIV/AIDS (Mathers \& Loncar, 2006; WHO, 2006).

The condition described in the global report is similar to the state of mental health in Indonesia. In the Basic Health Research (Riskesdas), the Ministry of Health (Kementerian Kesehatan, 2013) describes 
the prevalence of severe mental disorders, such as schizophrenia and other psychotic disorders, has reached $1.7 \%$ (per mile) of the population, meaning that more than 500,000 people suffer from severe mental illness. The highest spreads of severe mental disorders are in the Special Region of Yogyakarta and Aceh with the findings of $2.7 \%$. In the same survey, Riskesdas indicates a prevalence of emotional distress (depression \& anxiety) for about 6\% (Kementerian Kesehatan). From this number, it can be estimated that more than 14 million people in Indonesia experience emotional disturbance. In the same report, the Ministry of Health still found cases of "pasung" on $14.3 \%$ mental illness patients in various parts of Indonesia. The abuse is not only limited to the conventional ways (using chains or beams), but also in the form of control that restricts movement and isolation.

The spread of mental disorders is not supported by adequate availability of mental health services. A condition where patients are unable to obtain a proper treatment is called the treatment gap (Kale, 2002). Basically the treatment gap occurs due to low quality of healthcares and patients' failures to get treatment. The treatment gap occurs in many countries. A study conducted by Kohn, Saxena, Levav, and Saraceno (2004) found that the treatment gap in developing countries reached more than $90 \%$. Thus, only less than $10 \%$ of people with mental disorders received a proper treatment from mental health services. Kementerian Kesehatan (2013) also mentioned that the treatment coverages for patients with psychosis disorders and emotional disorders reached $61.8 \%$ and $26.6 \%$, respectively. Not to mention that the existing mental health facilities was unable to meet the needs for mental health services. Ultimately, this condition further deepens the gap in treatment imbalances.

The increase of mental disorder cases is also caused by patients' failures to get professional help (delayed initial treatment-seeking). Kohn et al. (2004) found that $60 \%$ of people with mental disorders experienced delays in getting help for years. Men were reported to have more tendencies of failing to get help compared to women (Wang et al., 2007). The longer the patients wait for professional help, the longer the healing process would take. A longer time span has other effects, such as increasing the possibility of resistance to treatment (de Diego-Adelino et al., 2010), increasing the risk of suicide (Altamura et al., 2010), decreasing cognitive functions (Rund et al., 2004), and also increasing the risk of more severe relapse (Altamura, Dell'Osso, Vismara, \& Mundo, 2008).
The patients' failures to obtain professional help are not only caused by a single factor. It was found that the failure in getting treatment was due to patients' inability to identify symptoms of mental disorders (Gulliver, Griffiths, \& Christensen, 2010). In other findings, the low levels of social support and patients' withdrawal to receive assistance extended the length of treatment (Burleson, 2003; Gulliver, Griffiths, \& Christensen, 2010). In addition, some researchers (Corrigan \& Rao, 2012; Lucksted \& Drapalski, 2015; Sarwono \& Subandi, 2013) also mentioned that the stigma of mental disorders resulted in patients refusing to seek medical treatment and preferring a traditional approach. A false understanding of mental disorders was found to have lowered the belief about treatment (Masuda \& Latzman, 2011). Meanwhile, the assistance from surroundings to access mental health services can reduce the length of treatment $\left(\mathrm{O}^{\prime}\right.$ Connor, Martin, Weeks, \& Ong, 2014). With this in mind, the help from the surroundings can bridge the access for mental health personnel. The help can break the chain of patients' failures in getting treatment.

Providing mental health help is the same behavior as volunteering or any other altruism behaviors. Angermeyer and Matschinger (1996) explained that providing mental health help is a prosocial act. In line with that opinion, Yap, Wright, and Jorm (2011) said that first aid actions taken by young people for mental health problems in a close friend; and Jorm (2015) said that providing mental health help is an effort to develop a healthy mental condition and eliminate a mental crisis condition. Some of the factors affecting this action include the experiences of providing prior help to people with mental disorders and mental health literacy (Jorm, Wright, \& Morgan, 2007; Rossetto, Jorm, \& Reavley, 2014). Mental health literacy is one's knowledge and beliefs about mental health (Jorm, 2015; Kutcher, Wei, \& Coniglio, 2016). Mental health literacy is also related to how one's consciousness seek and provide mental health help (Jorm, 2015). In another study, it was found that age factor affected the form of mental health help (Olsson \& Kennedy, 2010). Adults were found to be more likely to provide assistance for accessing mental health services rather than teenagers. In addition, women were also found to have a higher intensity of help-giving rather than men (Yap, Reavley, \& Jorm, 2012).

In addition, the attitude of providing help can predict a person's actions to provide help. This attitude is related to a person's judgment and readiness to provide help. Amato (1990) said that helpful atti- 
tudes include assessing various situations, such as assessing the characteristics of beneficiaries, the ability of aid providers and the situations in which the provision of assistance is possible. Thus, the attitude of giving help predicts planned assistance rather than spontaneous assistance. In addition, some researchers found a difference in providing assistance for people living in urban and rural areas (Köster, Schuhmacher, \& Kärtner, 2015; Scott \& Roberto, 1987). The difference is influenced by different patterns of interactions in rural and urban communities. Urban communities are known to have autonomous-personal interactions, while villagers have more interpersonal relations (Köster, Schuhmacher, \& Kärtner, 2015).

Given the above conditions, a person's participation in providing help to people with mental disorders (ODGM) is important. However, help giving can be hampered. Referring to Safitri's (2011) and Suarez's (2011) report, ODGM did not get the needed help due to a false judgement towards mental disorders. Poor knowledge of mental health has resulted in a false judgement of mental disorders. This view do not see mental disorders as biological-psychological problems (neurons, hormones and behavior), but as a magicalsupernatural influence. Such an understanding then encourages the help and treatment with a magicalsupernatural approach. This eventually extends the treatment length (duration untreated intervention) and the patient is reported to be late in getting professional help (Bottlender et al., 2003). Safitri (2011) and Suarez (2011) found that people in general were unable to accept people with mental disorders as part of their group. Ultimately, people with mental disorders receive discriminatory treatment.

A false understanding of mental disorders is called a stigma of mental disorders. The public understanding of mental disorders is influenced by beliefs and attitudes of groups from different cultures (Angermeyer $\&$ Dietrich, 2006). Corrigan and Watson (2002) explains that stigma can adversely affect patients in the form of prejudice and discriminatory treatments throughout their lives. Some researchers explain that stereotypes, prejudices and discrimination are the stigma chains of mental disorders that are closely related (Corrigan, 2004; Rüsch, Angermeyer, \& Corrigan, 2005). The stigma of mental disorders also influences the provision of help. Angermeyer and Matschinger (1996) found that the stigma of mental disorders can decrease the intensity of providing help. Prospective helpers may have emotion of fear, anxiety and anger when confronted with a person with a mental dis- order. This turns the person to become ignorant with patients with mental disorders.

There was only little research on the attitude of providing mental health help in Indonesia. Most existing research was conducted in western countries. The results of this study were expected to contribute to mental health studies in Indonesia. The study sought to examine if public stigma of mental disorder had a relationship with attitude of providing mental health help. Furthermore, we proposed a hypothesis that there was a negative relationship between public stigma of mental disorders and attitude of providing mental health help.

\section{Method}

The independent variable in this study was public stigma of mental disorders. The public stigma of mental disorders is a misconception and false belief about mental disorders that can affect people's attitudes and actions towards mental disorders. The scale of public stigma was constructed from Corrigan (2004), including cognitive (stereotype), attitude (prejudice), and behavior (discrimination) aspects.

The dependent variable in this study was attitude of providing mental health help. This attitude indicates the intensity of a person in providing mental health help in order to develop a healthy mental condition and eliminate crisis conditions. The scale was constructed from Kitchener and Jorm (2008), including the ability to: (a) approach patients and assess the risks; (b) listen carefully without judging patients' condition; (c) provide appropriate information; (d) encourage or facilitate patients to visit mental health professionals; and (e) provide other assistance to support healing.

This study used a cross-sectional design and was conducted in one of the universities in Yogyakarta. A total of 203 people were involved as research participants (women $n=159 ; \bar{X}$ age $=19.55$ ) and selected by accidental sampling. The inclusion criterion was having mental health knowledge. Thus, students from the school of psychology $(n=101)$, medicine $(n=48)$ and nursing $(n=54)$ were selected as participants as they had to attend mental health or abnormalities courses. Participants provided their answers directly on the scales of mental health assistance attitudes $(\alpha$ $=.90)$ and public stigma of mental disorder $(\alpha=.90)$. A description of the participant characteristics can be seen in Table 1 . 
Table 1

Participant Characteristics

\begin{tabular}{|c|c|c|c|}
\hline No. & Characteristic & Total & $\%$ \\
\hline \multirow[t]{6}{*}{1.} & Age & & \\
\hline & $\leq 17$ & 8 & $4 \%$ \\
\hline & $18-21$ & 162 & $80 \%$ \\
\hline & $\geq 22$ & 29 & $14 \%$ \\
\hline & Not Answering & 4 & $2 \%$ \\
\hline & Total & 203 & $100 \%$ \\
\hline \multirow[t]{4}{*}{2.} & Gender & & \\
\hline & Male & 44 & $22 \%$ \\
\hline & Female & 159 & $78 \%$ \\
\hline & Total & 203 & $100 \%$ \\
\hline \multirow[t]{5}{*}{3.} & Educational Background & & \\
\hline & Psychology & 101 & $49.75 \%$ \\
\hline & Medicine & 48 & $23.65 \%$ \\
\hline & Nursing & 54 & $26.60 \%$ \\
\hline & Total & 203 & $100 \%$ \\
\hline \multirow[t]{4}{*}{4.} & Residence & & \\
\hline & Rural & 70 & $34 \%$ \\
\hline & Urban & 133 & $66 \%$ \\
\hline & Total & 203 & $100 \%$ \\
\hline
\end{tabular}

The result of normality assumption test showed that data were not normally distributed, and therefore, data were analyzed using a nonparametric statistical analysis. The relationship of the two variables was tested using Charles Spearman's rank-order analysis. Furthermore, additional data were analyzed using the Mann-Whitney U-test to determine differences by gender and residence (rural $v s$. urban areas).

\section{Results}

Out of 215 participants, data from 12 participants were dropped. The result of linearity assumption test showed a linear relationship ( $p=.00, p<.05)$, however, the result of the Kolmogorov-Smirnov normality test showed that data were not normally distributed $(p=.00 ; p>.05)$. Based on these considerations, nonparametric statistical tests were used for further analyses. A Spearman correlation test resulted $r=-.45$ $(p=.00 ; p<.05)$. It showed that the proposed hypothesis was accepted. Public stigma of mental disorders had a negative relationship with attitude of providing mental health help. The contribution of public stigma variable to attitude of providing mental health help was $20.09 \%$.

Additional analyses were undertaken by considering other factors, such as group differences by gender and participants' residence (rural vs. urban areas). It was found that there was no difference in the atti- tudes of providing mental health assistance according to gender with the value of $Z=-0.58(p=.55 ; p$ $<.05)$ and to residence (rural $v s$. urban) with the value of $Z=-1.16(p=.24 ; p<.05)$.

\section{Discussion}

The results of this study showed a negative relationship between public stigma of mental disorders and attitudes of providing mental health help $(r=-.45$; $p<.05)$. This study found the possibility that public stigma of mental disorders is one factor that could reduce a person's positive attitude towards providing mental health help. The contribution of public stigma to the attitude of providing help was $20.09 \%$. Inaccurate public assumptions about mental disorders have widened the gap between patients and their surroundings. A misconception about mental disorders can also increase prejudice against potential helpers. In other words, potential aid providers are often discouraged in providing help because of their lack of understanding concerning how to provide help and what kind of help they can provide. Even so, public stigma is also considered to encourage discriminatory actions that might harm people with mental disorders.

The results of this study are consistent with the findings of Corrigan, Watson, Warpinski, and Gracia (2004) that the stigma creates a distance between community and people with mental disorders. The public stigma of mental disorders also reflects how community and social groups respond to people with mental disorders. Corrigan (2004), for example, found that stigma affected how community recognized and identified symptoms of mental disorders. The community attributes the behaviors that are considered peculiar to certain categories. In addition, public judgement that has been accepted as a general consensus defines how patients are accepted and treated.

In a study conducted by Sarwono and Subandi (2013), it was found that public stigma affected the reintegration process of patients at post treatment. Furthermore, public stigma also resulted in psychological turmoil among patients with low self-insight. For example, patients might show a closed-off attitude, an embarrassment and a withdrawal. In such conditions, stigma could be an obstacle for patients to achieve healing and fulfilling life.

In a wider context, such misunderstandings also result in patients being unable to achieve the optimal quality of life. It is difficult for them to have a job, career achievement or life fulfillment, and a place to 
live (Corrigan, 2004; Wahl, 1999). Wahl indicated that people with mental disorders tend to have difficulties in getting a place to live and working. Homeowners consider that people with mental illness will cause problems in the future. People with mental disorders are also considered to have poor work performance, low concentration and act carelessly or dangerously in the work place. Thus, it is not uncommon that people who have recovered from mental illness still have difficulties in getting jobs and housing, and face social barriers.

A person's ability to provide mental health help is also influenced by his/her knowledge about mental health. Such knowledge can build aid providers' confidence in providing proper mental health help. In previous studies, it was found that a person with mental health literacy had a positive evalution towards people who suffered from mental disorders (Kutcher, Wei, \& Coniglio, 2016; Rossetto, Jorm, \& Reavley, 2014) and could provide help to others who experienced mental crisis (Jorm, 2015; Kitchener \& Jorm, 2008). Considering Corrigan's (2004), and Kutcher's, Wei's, and Coniglio's (2016) opinions that stigma of mental disorder is a misperception or misunderstanding towards mental disorders, it is concluded that a person with a high level of public stigma has a low level of mental health literacy.

This present study did not find a difference in attitude of providing help between participants who lived in rural and urban areas $(Z=-1.16 ; p>.05)$. Although some researchers found the differences in help-giving attitudes between rural and urban communities (Köster, Schuhmacher, \& Kärtner, 2015; Scott \& Roberto, 1987), other researchers found no differences (Dwyer \& Miller, 1990; Lee \& Cassidy, as cited in Scott \& Roberto, 1987).

The differences in providing help between men and women were not found in this study, which were in contrast with the previous findings. For example, a study (Burleson, 2003; Yap, Wright, \& Jorm, 2011) found that women were more likely to provide mental health assistance than men. However, this present study found no difference between men and women in the attitude of providing mental health help $(Z=-0.58 ; p>.05)$. The contrast in the results might be due to this present study focusing on attitudes rather than actions. Burleson explains that for women, the act of helping is closely related to affective support. The findings of Jorm, Wright, and Morgan (2007) showed that men tended to solve problems independently and were reluctant to interfere in others' affairs.

The ability to provide mental health help has a re- lationship with mental health literacy. Jorm (2015) argues that the ability to recognize symptoms of mental disorders will facilitate someone to provide an appropriate assistance. Meanwhile, Kutcher, Wei, and Coniglio (2016) state that if someone has decent mental health literacy, then he or she will have a low stigma towards mental disorders. From these opinions, it can be concluded that mental health literacy can facilitate a person to be able to provide mental health help and reduce the stigma of mental disorders.

This study has limitations, such as mental health knowledge was not measured in all research participants. Participants were selected based solely on the assumption that they had good mental health knowledge. This study do not involve participants with poor mental health knowledge, therefore, it is unknown if mental health knowledge affects the attitude of providing mental health help. Disproportionate demographic compositions of participants might influence the results in this study, thus, the actual differences between the two groups of participants are still unknown. This study is also limited to a group of students that results in participants with similar age range. The procedure in this study that is based on accidental sampling does not take into consideration the circumstances in data collection, with respect to participants and their surroundings. This study suggests that further research should consider having participants completing the scale at the same time to reduce the errors caused by differences in participants' conditions during the completion of scale.

\section{Conclusions}

This study found a negative relationship between public stigma of mental disorders and attitude of providing mental health help. The higher the public stigma towards mental disorders, the lower the person's attitude in providing mental health help. The public stigma of mental disorders was found to contribute as high as $20.09 \%$ to a decrease in the attitude of providing help to people with mental disorders. The study found that there were no differences in the attitude of providing mental health help based on gender and residence (rural vs. urban areas).

\section{Suggestions}

Based on the results, several points may be suggested, including: (1) increasing mental health awareness through mental health promotion activities; (2) campaigning for mental health awareness to reduce mis- 
conceptions about mental disorders; and (3) considering stigma of mental disorders in psychoeducation of mental health.

Based on our observation during data collection throughout data analyses, we propose suggestions for further research. With respect to the participant requirement for having an understanding of mental health, future studies should measure participants' understanding more objectively. This study involves participants with similar characteristics, such as similar age range and familiarity with mental health issues (students of psychology, medicine and nursing), further research may consider other demographic factors that may influence directly or indirectly the results of study. During data collection, future researchers should control the condition of participants that may affect the results of study, such as utilizing a special room for participants to complete the scale in order to reduce various factors that influence data collection.

\section{References}

Altamura, A. C., Dell'Osso, B., Berlin, H. A., Buoli, M., Bassetti, R., \& Mundo, E. (2010). Duration of untreated illness and suicide in bipolar disorder: A naturalistic study. European archives of psychiatry and clinical neuroscience, 260(5), 385391. http://dx.doi.org/10.1007/s00406-009-0085-2

Altamura, A. C., Dell'Osso, B., Vismara, S., \& Mundo, E. (2008). May duration of untreated illness influence the long-term course of major depressive disorder? European Psychiatry, 23(2), 92-96. http:// dx.doi.org/10.1016/j.eurpsy.2007.11.004

Amato, P. R. (1990). Personality and social network involvement as predictors of helping behavior in everyday life. Social Psychology Quarterly, 53(1), 31-43.

Angermeyer, M. C., \& Dietrich, S. (2006). Public beliefs about and attitudes towards people with mental illness: A review of population studies. Acta Psychiatrica Scandinavica, 113(3), 163-179. http:// dx.doi.org/10.1111/j.1600-0447.2005.00699.x

Angermeyer, M. C., \& Matschinger, H. (1996). The effect of personal experience with mental illness on the attitude towards individuals suffering from mental disorders. Social Psychiatry and Psychiatric Epidemiology, 31(6), 321-326. http://dx.doi. org/10.1007/bf00783420

Bottlender, R., Sato, T., Jäger, M., Wegener, U., Wittmann, J., Strauß, A., \& Möller, H. J. (2003).
The impact of the duration of untreated psychosis prior to first psychiatric admission on the 15-year outcome in schizophrenia. Schizophrenia Research, 62(1), 37-44. http://dx.doi.org/10.1016/S09 20-9964(02) 00348-1

Burleson, B. R. (2003). The experience and effects of emotional support: What the study of cultural and gender differences can tell us about close relationships, emotion, and interpersonal communication. Personal Relationships, 10(1), 1-23. http:// dx.doi.org/10.1111/1475-6811.00033

Corrigan, P. (2004). How stigma interferes with mental health care. American Psychologist, 59(7), 614625. http://dx.doi.org/10.1037/0003-066x.59.7.614

Corrigan, P. W., \& Rao, D. (2012). On the self-stigma of mental illness: Stages, disclosure, and strategies for change. Canadian Journal of Psychiatry, 57(8), 464-469.

Corrigan, P. W., \& Watson, A. C. (2002). Understanding the impact of stigma on people with mental illness. World Psychiatry, 1(1), 16-20.

Corrigan, P. W., Watson, A. C., Warpinski, A. C., \& Gracia, G. (2004). Implications of educating the public on mental illness, violence, and stigma. Psychiatric Services, 5(5), 577-580. http://dx.doi.org/ 10.1176/appi.ps.55.5.577

de Diego-Adeliño, J., Portella, M. J., Puigdemont, D., Pérez-Egea, R., Álvarez, E., \& Pérez, V. (2010). A short duration of untreated illness (DUI) improves response outcomes in first-depressive episodes. Journal of Affective Disorders, 120(1), 221225. https://dx.doi.org /10.1016/j.jad.2009.03.012

Dwyer, J. W., \& Miller, M. K. (1990). Differences in characteristics of the caregiving network by area of residence: Implications for primary caregiver stress and burden. Family Relations, 39, 27-37.

Gulliver, A., Griffiths, K. M., \& Christensen, H. (2010). Perceived barriers and facilitators to mental health help-seeking in young people: A systematic review. BMC Psychiatry, 10(1), 113. https:// dx.doi.org /10.1186/1471-244X-10-113

Jorm, A. F. (2015). Why we need the concept of "mental health literacy". Health Communication, 30(12), 1166-1168.

Jorm, A. F., Wright, A., \& Morgan, A. J. (2007). Beliefs about appropriate first aid for young people with mental disorders: findings from an Australian national survey of youth and parents. Early Intervention in Psychiatry, 1(1), 61-70. http://dx. doi.org/10.1111/j.1751-7893.2007.00012.x

Kale, R. (2002). The treatment gap. Epilepsia, 43(6), 31-33. http://dx.doi.org/10.1046/j.1528-1157. 43. 
s.6.13.x

Kementerian Kesehatan. (2013). Riset kesehatan dasar. Jakarta: Badan Penelitian dan Pengembangan Kesehatan Departemen Kesehatan Republik Indonesia.

Kitchener, B. A., \& Jorm, A. F. (2008). Mental health first aid: An international programme for early intervention. Early Intervention in Psychiatry, 2(1), 55-61. http://dx.doi.org/10.1111/j.1751-7893. 20 07.00056.x

Kohn, R., Saxena, S., Levav, I., \& Saraceno, B. (2004). The treatment gap in mental health care. Bulletin of The World Health Organization, 82(11), 858-866.

Köster, M., Schuhmacher, N., \& Kärtner, J. (2015). A cultural perspective on prosocial development. Human Ethology Bulletin, 30(1), 71-82.

Kutcher, S., Wei, Y., \& Coniglio, C. (2016). Mental health literacy past, present, and future. The Canadian Journal of Psychiatry, 61(3), 154-158. http:// dx.doi.org/10.1177/0706743715616609

Lucksted, A., \& Drapalski, A. L. (2015). Self-stigma regarding mental illness: Definition, impact, and relationship to societal stigma. Psychiatric Rehabilitation Journal, 38(2), 99-102. http://dx.doi. org/10.1037/prj0000152

Masuda, A., \& Latzman, R. D. (2011). Examining associations among factor-analytically derived components of mental health stigma, distress, and psychological flexibility. Personality \& Individual Differences, 51(4), 435-438. http://dx.doi.org/10. 1016/j.paid.2011.04.008

Mathers, C. D., \& Loncar, D. (2006). Projections of global mortality and burden of disease from 2002 to 2030. PLoS Medicine, 3(11), 2011-2030. http:// dx.doi.org/10.1371/journal.pmed.0030442

O'Connor, P. J., Martin, B., Weeks, C. S., \& Ong, L. (2014). Factors that influence young people's mental health help-seeking behaviour: A study based on the health belief model. Journal of Advanced Nursing, 70(11), 2577-2587. http://dx.doi.org/ 10.1111/jan. 12423

Olsson, D. P., \& Kennedy, M. G. (2010). Mental health literacy among young people in a small US town: Recognition of disorders and hypothetical helping responses. Early Intervention in Psychiatry, 4(4), 291-298. http://dx.doi.org/10.1111/ j.1751-7893.2010.00196.x

Rossetto, A., Jorm, A. F., \& Reavley, N. J. (2014). Examining predictors of help giving toward people with a mental illness. SAGE Open, 4(2), 1-11. http://dx.doi.org/10.1177/2158244014537502
Rund, B. R., Melle, I., Friis, S., Larsen, T. K., Midbøe, L. J., Opjordsmoen, S., ... \& McGlashan, T. (2004). Neurocognitive dysfunction in first-episode psychosis: Correlates with symptoms, premorbid adjustment, and duration of untreated psychosis. American Journal of Psychiatry, 161(3), 466-472. http://dx.doi.org/10.1176/appi.ajp.161.3.466

Rüsch, N., Angermeyer, M. C., \& Corrigan, P. W. (2005). Mental illness stigma: Concepts, consequences, and initiatives to reduce stigma. European Psychiatry, 20(8), 529-539. http://dx.doi.org/10. 1016/ j.eurpsy.2005.04.004

Safitri, D. (2011). Bukan gila, tetapi menderita sakit mental. Retrieved from http://www.bbc.com/indo nesia/laporan_khusus/2011/10/111004_mental1

Sarwono, R. B., \& Subandi (2013). Mereka memanggilku "kenthir". Jurnal Psikologi, 40(1), 1-14. http:// dx.doi.org/10.22146/jpsi.7062

Scott, J. P., \& Roberto, K. A. (1987). Informal supports of older adults: A rural-urban comparison. Family Relations: An Interdisciplinary Journal of Applied Family Studies, 36(4), 444-449.

Suarez, R. (2011). Indonesia's mentally ill face neglect, mistreatment. PBS News Hour. Retrieved from http://www.pbs.org/newshour/bb/health-julydec11-mentalhealth_07-18/

Wahl, O. F. (1999). Mental health consumers' experience of stigma. Schizophrenia Bulletin, 25(3), 467478.

Wang, P. S., Angermeyer, M., Borges, G., Bruffaerts, R., Chiu, W. T., De Girolamo, G., ... \& Kessler, R. C. (2007). Delay and failure in treatment seeking after first onset of mental disorders in the World Health Organization's World Mental Health Survey Initiative. World Psychiatry, 6(3), 177-185.

World Health Organization. (2001). The world health report 2001: Mental health: New understanding, new hope. Geneva: WHO.

World Health Organization. (2006). WHO statistical information system: Working paper describing data sources, methods, and results for projections of mortality and burden of disease for 2005, 2015, 2030. Geneva: WHO.

Yap, M. B. H., \& Jorm, A. F. (2011). The influence of stigma on first aid actions taken by young people for mental health problems in a close friend or family member: Findings from an Australian national survey of youth. Journal of Affective Disorders, 134(1), 473-477. http://dx.doi.org/10.101 6/j.jad.2011.05.039

Yap, M. B. H., Reavley, N. J., \& Jorm, A. F. (2012). Intentions and helpfulness beliefs about first aid 
responses for young people with mental disorders: Findings from two Australian national surveys of youth. Journal of Affective Disorders, 136(3), 430442. http://dx.doi.org/10.1016/j.jad.2011.11.006

Yap, M. B. H., Wright, A., \& Jorm, A. F. (2011). First aid actions taken by young people for mental health problems in a close friend or family member: Findings from an Australian national survey of youth. Psychiatry Research, 188(1), 123-128. http:// dx.doi.org/10.1016/j.psychres.2011.01.014 